two pages of text. Mr. Hawken and the LTP have followed their Photocopying From Bound Volumes with a worthy successor.Hubbard W. Ballou, Columbia University Libraries.

Engineering Data Microreproduction Standards and Specifications. By the United States Department of Defense. (Informational Monograph No. 1) Annapolis, Md.: National Microfilm Association, 1963. 15lp. \$3.

A phrase that occurs many times in variant forms in William Hawken's recent book on enlarged prints from microforms is: "This machine was never designed to reproduce the diverse sizes and types of documents which make up library collections of microforms." In his summary chapter he throws down his gage before the equipment manufacturers challenging them to: “. . . take another look at the library world, its vast holdings of microforms, and its needs." We can say "Hear, hear!" to this, but in all honesty can we not grant the manufacturers a valid counter-challenge to us to do something about standardizing the production of our library microforms, so that they may design us simplified and inexpensive models?

A field which was faced with a similar problem was that of engineering drawing files. The Department of Defense wanted to simplify the storage, dissemination, and reproduction of these bulky items through use of microfilm. These drawings occur in multifarious sizes and of indescribably varying qualities of legibility. The only way to make the system work was by standardization all along the line: production of the original drawing, filming, processing, mounting the film in tab cards, and reproduction through numerous generations to the final paper print output.

The National Microfilm Association has been active in the progress of the Engineering Data Microreproduction System since serious work began on it about 1956. The association, at its San Francisco convention in April 1963, reprinted the many scattered specifications that were the outgrowth of this program. Though available as twelve separate specifications from the various agencies involved, this package publication is the easiest and cheapest way to acquire the series. Written as federal specifications are, they are not designed as light reading matter; but there is much food for thought buried beneath the official jargon. Libraries can learn by analogy from problems faced by the DOD EDMS program, and get what cheer they can from knowing that other users of microreproductions have met the same problems. One warning is necessary, however, and that is that the two problems are similar but not replicas of each other. We must pick and choose those points of similarity with care, and not try to specify all items from the DOD specs every time we place an order for microfilming.-Hubbard W. Ballou, Columbia University Libraries.

\section{Latin American Directory}

Guia de Bibliotecas de la América Latina. Edición provisional. (Pan American Unión, Columbus Memorial Library. Bibliographic Series, no. 51) Washington: Union Panamericana, 1963. viii 165 p. $\$ 5$.

For some time the lack of a guide to Latin American libraries-similar to the American Library Directory-has hampered persons needing information about such institutions. The many changes in the library picture there since 1942 have, of course, rendered Rodolfo O. Rivera's Preliminary List of Libraries in the Other American Republics inadequate for most purposes. The present compilation, prepared by the Pan-American Union's Library Development Program, while not fully comparable to the Bowker list, represents a step in the right direction.

Although the compilers have not attempted to include all Latin American libraries, their aim was to present all university and special libraries, public libraries of more than two thousand volumes, and school libraries of more than one thousand volumes; they recognize that, even with these limits, they have probably missed some institutions. Nevertheless, the user finds approximately twenty-two hundred libraries (vs. five thousand in the less selective $\mathrm{Ri}$ vera list); there is a section for each of the twenty Latin American republics and Puer- 
to Rico, with subdivisions by city. The directory tries to bring together in one place the component libraries in a system (e.g., the public library and its branches in a given city or the various faculties and institutes of a university), but it does not do so for universities with facilities in several cities. Each entry contains the following information: name and address of library, name of librarian, number of volumes, date established, type of library (public, university, school or special), subject specialization (only one or two given), and whether or not the library exchanges publications. The fact that the data is in Spanish should cause no problem to non-Spanish readers, because there is no text other than the preface, and the terms which occur in the listings are either cognates, or may be found quickly in any Spanish-English dictionary.

The preface points out the difficulty of obtaining up-to-date information on the size of libraries and the names of their librarians, and a special note for the section devoted to Cuba warns that there is much pre-1959 information which could not be made current. This perhaps explains why some of the statistics presented are at variance with those found in other sources (e.g., The World of Learning) and those obtained in personal contact with library staffs.

Although the compilers apparently did not feel it to be a part of their task, an analysis of the data collected would have given a useful quantitative picture of Latin American libraries. For example, a count of libraries by country shows that Brazil, Argentina, Mexico, and Colombia are (as one might expect) far in the lead; each reports two hundred or more-a figure which no other nation approaches. This reader noted 126 libraries of over fifty thousand volumes each, with the ten largest being, in descending order: National Library of Brazil, National Library of Chile, General Administration of Archives, Libraries, and Museums (Chile), National Library of Argentina, Faculty of Medicine (University of Buenos Aires), the national libraries of Uruguay, Mexico, Venezuela, and Colombia, and the University of La Plata (Argentina).

That the compilers recognize the shortcomings of this directory is clearly indicated by the fact that it carries the label "pro- visional edition." This reviewer offers the following suggestions for incorporation into the final version: (1) coverage on a more uniform basis of such types of libraries as those of university faculties and institutes and those of the bi-national centers; (2) expansion of listings to include the newly independent nations of the Caribbean and the remaining European possessions in the area, thus making the directory comprehensive for the entire area south of the Rio Grande; (3) enlarging the data on each library to include size of staff, budget, volumes circulated and possibly publications issued; (4) analysis, perhaps in an introductory section, of the information presented; and (5) preparation of an index of names of libraries and librarians and of the subject specialties indicated. Perhaps this is too much to expect from the limited staff of the Library Development Program without outside assistance from a university or foundation, but the problem might be attacked over a period of time by dividing the compilation into several regional volumes or even separate directories for each type of library.

There is no doubt, however, that until a replacement for this provisional edition appears, it will serve not only as a useful directory but also as a guide to potential exchange sources among libraries in the Americas.-William Vernon Jackson, University of Wisconsin.

\section{Information Retrieval}

\section{Nonconventional Technical Information} Systems in Current Use. No. 3. Washington, D.C.: National Science Foundation, October 1962. xx, 209p.

In January of 1958, the National Science Foundation published a slender pamphlet of forty-three pages under the title Nonconventional Technical Information Systems in Current Use. This compilation, prepared by Madeline Berry (now Mrs. Henderson) of the NSF Scientific Documentation Program, described twenty-four "technical information systems, currently in operation, embodying new principles for the organization of subject matter or employing automatic equipment for storage and search." 